Journal of International Economic Integration 2(1). Spring 1987, 1-23.

\title{
The Employment and Wage Effects of Import Competition in the United States
}

\begin{abstract}
Gene M. Grossman*
A new methodology is developed to determine the extent to which imports have been responsible for labor displacements and wage movements in specific, allegedly trade-impacted sectors. The procedure involves the estimation of reduced-form wage and employment equations by sector. The proposed methodology is applied to nine manufacturing sectors in the United States. Counterfactual simulations are performed under the hypothetical assumption of no intensification or abatement of import competition from 1967-1979. The simulations show that imports have been responsible for the loss of a large number of jobs in only one industry, and for a significant loss in wages in two industries, among the nine studied.
\end{abstract}

\section{Introduction}

How important is import competition as a cause of labor displacements and wage movements? It is generally believed that increased competition from abroad in particular sectors can have only negligible effects on the aggregate levels of employment and wages, these variables being primarily determined by macroeconomic events and policies. But shifts in comparative advantage, just as any structural changes, may in principle necessitate large movements of resources from declining sectors to expanding sectors; and if resources are not perfectly mubile, these reallocations may be accompanied by large changes in the rewards earned by factors of production that do not move. Thus, import competition has often been regarded as a prime cause of injury to workers located in adversely affected sectors, and

\footnotetext{
-Woodrow Wilson School, Princeton University, U.S.A.
}

I would like to thank Jagdish Bhagwati for suggesting this topic of research to me, and Alan Deardorff, Avinash Dixit, Rudi Dornbusch, Carl Hamilton, John Martin and David Richardson for helpful comments. Robert Johnson and David Zimble provided able research assistance. Financial support was provided by the International Labor Affairs Bureau, U.S. Department of Labor, and by the National Science Foundation under Grant No.PRA-8211940. 
presumably as a source of gain to workers in those sectors which have benefitted from shifts in the pattern of trade.

Even the limited view that a substantial number of jobs in specific sectors have been lost to competitors abroad has been challenged in a number of recent writings. Krueger (1979a, 1979b, 1980a and 1980b), Frank (1977), Cable (1977) and Wolter (1979) have argued that, relative to other structural changes that occur in a dynamic economy due to, for example, differences in the rates of technological progress across sectors, differences in the income elasticities of demand across goods and differences in the rates of accumulation of alternative factors of production, import competition has been only a minor factor in labor displacement.

Unfortunately, the methodology used by all of these authors to draw this conclusion is seriously flawed. It relies on an accounting decomposition that allegedly separates changes in sectoral levels of employment into their proximate causes. As I have shown elsewhere(Grossman, 1982a), this procedure does not have general validity. Unless factor substitution in production is impossible, the accounting approach may, for example, attribute job displacements to technological change which were in fact precipitated by intensification of import competition. Put differently, the accounting procedure is incapable of distinguishing shifts in isoquants from movements along isoquants. A further difficulty with this approach is that it identifies the extent of import competition by the share of imports in domestic consumption. This measure is inappropriate, because the share variable varies not only with shifts in the foreign supply curve for imports, but also with changes in conditions of supply in the domestic industry. ${ }^{1}$

In Section II, I develop an alternative methodology to address the question raised at the outset. The procedure I propose involves econometric estimation of reducedform, industry-level, wage and employment equations. ${ }^{2}$ These equations are derived from a complete set of structural equations that together determine factor allocations and factor prices by sector. The advantage of this approach is that it allows direct

1. Martin and Evans (1981) have noted several other difficulties with such accounting decompositions.

2. Since completing this paper, two articles which bear some similarility to the present study were pointed out to me. Saxonhouse (1972) derives a reduced form employment equation from a structural model, substitutes "guestimates" of the underlying structural parameters, and then inserts historical data for the exogenous variables to attribute employment changes to various causes. Pelzman and Martin (1981), in their study of the textile industry, estimate first the effect of tariff changes on import demand, then the effect on domestic supply of changes in the quantity of imports, and finally the output elasticity of industrty employment. Neither study identifies import competition with shifts in the foreign supply curve, and both treat industry wages as exogenous. Furthermore, neither asks the sort of counterfactural questions which are the focus here. 
measurement of the sensitivity of sectoral employment and wage levels to shifts in the supply of imports. When the methodology is applied to nine manufacturing industries in the United States, using monthly data from 1969 through 1979, it yields quite plausible parameter estimates.

In Section III, I define an appropriate measure of change in the extent of import competition faced by an industry Paths for employment and wages for the nine industries are then simulated under the counterfactual assumption that import competition was "neutral" (i.e., did not intensify or abate) during the entire period from 1967 to 1979 . These paths are compared to those for actual employment and wages in the sectors, and the differences are attributed to changes in the intensity of competition from abroad.

Section IV contains a summary of the findings.

\section{Sensitivity to Import Competition : \\ A New Methodology}

In this section, I describe a methodology that can be used to estimate the sensitivity of sectoral levels of employment and wages to changes in certain structural variables. The variables, which are exogenous with respect to activity in any particular, small sector, are those which together determine the general equilibrium allocation of resources. Among the variables is the price of the foreign good that competes with domestic output, which will be assumed to represent the location of a perfectly-elastic, foreign supply curve. ${ }^{3}$ The approach I take involves the specification of reduced-form wage and employment equations. These are first derived from a more complete, structural model. Then, to test the methodology in application, I have estimated nine such pairs of equations for various U.S. manufacturing sectors.

I begin with the specification of the long run equilibrium, and postpone for the moment discussion of the process of adjustment to this equilibrium. Consider then a three-factor, many-good model of international trade with imperfect substitutability between home goods and foreign goods and partial mobility of factors between sectors.

3. In principle, the proposed methodology could be carried out without the assumption that the foreign import supply curve is perfectly elastic. However, without this assumption it would be necessary to collect data on the structural variables for all the countries that export to the United States in order to distinguish movements along a supply curve from shifts in the curve. Richardson (1974) has shown that the assumption that the United States is small in the market for its imports may be justified for many manufactured goods. 
The output, $\mathrm{Y}_{i}$, of a representative, importable-goods sector $i$ is produced with the input of labor, $\mathrm{L}_{i}$, capital, $\mathrm{K}_{i}$ and "energy", $\mathrm{E}_{i}$, according to the Cobb-Douglas production function

$$
\mathrm{Y}_{i}=\mathrm{Ae}^{\pi} \mathrm{K}_{i}^{\mathrm{a}_{1}} \mathrm{~L}_{i}^{\mathrm{a}_{2}} \mathrm{E}_{i}^{\left(1-\mathrm{a}_{i}-\mathrm{a}_{2}\right)} \quad \mathrm{a}_{1}, \mathrm{a}_{2}, \mathrm{~A}>0
$$

Here $\pi$ is the rate of Hicks - neutral technological progress and t denotes time.

Energy is assumed to be a traded input, available to sector $i$ in infinitely-elastic supply at an exogenous price, $\mathrm{Pe} .{ }^{4}$ The quantity of energy input used by a profitmaximizing industry is found by setting its value marginal product equal to its price, or

$$
\mathrm{E}_{i}=\frac{\left(1-\mathrm{a}_{1}-\mathrm{a}_{2}\right) \mathrm{P}_{i} \mathrm{Y}_{i}}{\mathrm{P}_{\mathrm{e}}}
$$

Where $\mathrm{P}_{i}$ is the price of sector $i$ 's output. Capital and labor are nontraded factors, and their aggregate stocks are taken to be exogenous, at least with respect to activity in a small sector. The derived demands for capital and labor are given by, respectively,

$$
\begin{aligned}
& \mathrm{K}_{i}=\frac{\mathrm{a}_{1} \mathrm{P}_{i} \mathrm{Y}_{i}}{\mathrm{r}_{i}}, \\
& \mathrm{~L}_{i}=\frac{\mathrm{a}_{2} \mathrm{P}_{i} \mathrm{Y}_{i}}{\mathrm{w}_{i}},
\end{aligned}
$$

Where $r_{i}$ is the rental rate on capital prevailing in sector $i$, and $\mathrm{w}_{i}$ is the wage rate there.

Capital and labor are assumed to be partially, but (potentially) imperfectly mobile between sectors, even in the long run. ${ }^{5}$ The fraction of the aggregate stock of each factor that is supplied to sector $i$ is a function of the ratio of its reward in that sector to its aggregate rate of return. Letting $\mathrm{K}_{\mathrm{a}}$ and $\mathrm{L}_{\mathrm{a}}$ be the aggregate stocks of capital and labor, respectively, and $\mathrm{r}_{\mathrm{a}}$ and $\mathrm{w}_{\mathrm{a}}$ be their aggregate returns, we have ;

4. The energy variables was included largely to capture the structural effects on employment and wages of the oil price increase. This explains why energy is modolled here as a traded good.

5. For a discussion of partial factor mobility in the standard trade models, see Mussa (1982) or Grossman (1983). The particular modelling of intersectoral factor mobility used here is similar to that in Hill and Mendez (1983). 


$$
\begin{array}{ll}
\frac{\mathrm{K}_{i}}{\mathrm{~K}_{\mathrm{a}}}=\mathrm{C}\left(\frac{\mathrm{r}_{i}}{\mathrm{r}_{\mathrm{a}}}\right)^{\mathrm{c}}, & \mathrm{c}, \mathrm{C}>0 \\
\frac{\mathrm{L}_{i}}{\mathrm{~L}_{\mathrm{a}}}=\mathrm{D}\left(\frac{\mathrm{w}_{i}}{\mathrm{~W}_{\mathrm{a}}}\right)^{\mathrm{d}}, & \mathrm{d}, \mathrm{D}>0
\end{array}
$$

The advantage of this specification for empirical implementation, relative to the more standard perfect-mobility assumption, is that it does not impose on the data the constraint that wage rates or rates of return on capital eventually be equated across industries. Differences in payments to factors located in different sectors can persist if factors are not homogeneous, and if different skills or attributes are required in various activities. Also, if workers have preferences over occupations of industries, so that these enter utility along with income, then wages will not be equal everywhere in the economy. Note that even casual empirical observation suggests that factors do not earn the same rates of pay in all manufacturing industries in the U.S. economy. Of course, the present specification does not preclude there being a very high degree of intersectoral mobility, in which case we would expect the parameters $\mathrm{c}$ and $\mathrm{d}$ to be nearly infinite.

The real aggregate rates of return are determined by the aggregate stocks of the nontraded factors and the price of the traded factor, according to:

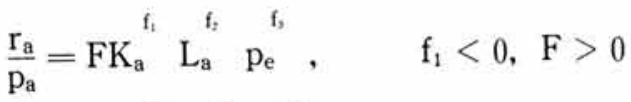

$$
\begin{aligned}
& \frac{\mathrm{W}_{\mathrm{a}}}{\mathrm{p}_{\mathrm{a}}}=\mathrm{GK}_{\mathrm{a}}^{\mathrm{g}_{\mathrm{i}}} \stackrel{\mathrm{L}_{\mathrm{a}}}{\mathrm{g}_{\mathrm{a}}} \mathrm{p}^{\mathrm{g}_{\mathrm{b}}}, \quad \mathrm{g}_{2}<0, \mathrm{G}>0
\end{aligned}
$$

Where $\mathrm{p}_{\mathrm{a}}$ is the aggregate price level.

Finally, the output of sector $i$ is assumed to substitute imperfectly for the import $\operatorname{good}\left(\right.$ with exogenous price $\mathrm{p}_{i}^{*}$ ) and for the aggregate basket of domestic goods. The demand facing this industry (which in equilibrium is equal to its output) is given by :

$$
\mathrm{Y}_{i}=\mathrm{B}\left[\frac{\mathrm{P}_{i}^{*}\left(1+\tau_{i}\right)}{\mathrm{P}_{i}}\right] \quad\left(\frac{\mathrm{P}_{\mathrm{a}}}{\mathrm{P}_{i}}\right) \quad \mathrm{Q} \quad \mathrm{b}_{1}, \mathrm{~b}_{2}>0, \mathrm{~B}>0
$$

Where $\mathrm{Q}$ is real national income and $\tau_{i}$ is the applicable ad valorem tariff rate. There are nine equations, (2.1) through (2.9) which together determine the nine endogenous variables, $\mathrm{Y}_{i}, \mathrm{~K}_{i}, \mathrm{~L}_{i}, \mathrm{E}_{i}, \mathrm{p}_{i}, \mathrm{r}_{i}, \mathrm{w}_{i}, \mathrm{r}_{\mathrm{a}}$ and $\mathrm{w}_{\mathrm{a}}$, as a function of the exogenous variables, $\mathrm{K}_{\mathrm{a}}, \mathrm{L}_{\mathrm{a}}, \mathrm{p}_{\mathrm{e}}, \mathrm{p}_{\mathrm{a}}, \mathrm{p}_{i}^{*}, \tau_{i}$ and $\mathrm{Q}$. 
In principle, it would be possible to jointly estimate these nine equations for a chosen sector. However, the difficulty one would encounter in collecting a consistent set of data makes this procedure extremely impractical. Fortunately, an alternative approach can be taken. Our interest is in the effect of shifts in the foreign supply curve (i.e., changes in $p_{i}^{*}\left(1+\tau_{i}\right)$, given our assumption of perfectly-elastic supply) on employment and wages in the domestic industry. This is essentially a question about the reduced form of equations (2.1) to (2.9), so we may solve out for this reduced form, and estimate it directly. By doing so, we sidestep the task of collecting data for many of the endogenous variables.

The reduced form equations for $\mathrm{L}_{i}$ and $\mathrm{w}_{i}$ are, after taking logs, as foolows:

$$
\begin{aligned}
& \log \mathrm{L}_{i}=\alpha_{0}+\alpha_{1} \mathrm{t}+\alpha_{2} \log \mathrm{K}_{\mathrm{a}}+\alpha_{3} \log \mathrm{L}_{\mathrm{a}}+\alpha_{4} \log \mathrm{p}_{\mathrm{e}}+ \\
& \alpha_{5} \log \mathrm{p}_{\mathrm{a}}+\alpha_{6} \log \left(\mathrm{p}_{i}^{*}\left(1+\tau_{i}\right)\right)+\alpha_{7} \log \mathrm{Q}, \\
& \log \mathrm{w}_{i}=\beta_{0}+\beta_{1} \mathrm{t}+\beta_{2} \log \mathrm{K}_{\mathrm{a}}+\beta_{3} \log \mathrm{L}_{\mathrm{a}}+\beta_{4} \log \mathrm{p}_{\mathrm{e}}+ \\
& \beta_{5} \log \mathrm{p}_{\mathrm{a}}+\beta_{6} \log \left(\mathrm{p}_{i}^{*}\left(1+\tau_{i}\right)\right)+\beta_{7} \log \mathrm{Q} .
\end{aligned}
$$

Of particular interest are the coefficients $\alpha_{6}$ and $\beta_{6}$. These measure the elasticities of domestic employment and wages with respect to the price of the competing import good. In terms of the structural parameters, it can be shown that :

$$
\alpha_{6}=\frac{b_{1} d}{\frac{\left(b_{1}+b_{2}-1\right)(1+d) a_{1}}{1+c}+\left(b_{1}+b_{2}-1\right) a_{2}-(1+d)}
$$

and

$$
\beta_{6}=\alpha_{6} / \mathrm{d}
$$

According to the theory outlined above, both $\alpha_{6}$ and $\beta_{6}$ should be positive, reflecting the intuitive notion that a weakening of import competition should raise employment and wages in the domestic industry. The mechanism that applies here is the following one. An upward shift in the foreign supply curve, manifested as a rise in the price of imports, causes substitution in demand to the domestic good. This induces a rise in the domestic price, and therefore an upward shift in the derived demand for factors of production. The ultimate result is an increase in factor inputs and in factor prices, the division between them depending upon the elasticities of factor supplies to the sector.

Evidently, both employment and wages will be more sensitive to import 
competition the larger is $b_{1}$ and the smaller is $b_{2}$. The more mobile is labor, the more responsive is employment and the less so are wages. Finally, the sensitivity of both wages and employment to changes in $\mathrm{p}_{i}^{*}$ increases with the degree of capital mobility if and only if $b_{1}+b_{2}>1$; i.e., if demand for the sector's output is inelastic with respect to its own price.

The discussion thus far has concentrated solely on the long-run equilibrium allocation of resources. However, the process of adjustment in response to shocks to equilibrium can be prolonged if there are substantial costs to immediate relocation of factors, or if information about changing structural conditions is slow to diseminate. Since monthly data were used in the estimation described below, it certainly is not reasonable to assume that all observations constitute long-run equilibrium situations.

Unfortunately, relatively little is known with confidence about the dynamics of adjustment in factor markets. For this reason, it seems inappropriate to specify in detail a particular adjustment process, and impose the associated theoretically-derived restrictions on the parameters of the reduced-form equations. Instead, I assumed that whenever a change in one of the exogenous variables on the right hand side of equations (2.10) and (2.11) occurs, the long-run levels of the wage and employment in the industry are attained only after a period of time, the length of the lag depending on the nature of the shock.

It was assumed on a priori grounds that cyclical effects (associated with changes in real income) are felt most quickly, that changes in the prices of substitutes for the domestic product are somewhat slower to affect resource allocation (since the existence of a backlog of orders or contracts or of long-standing supplier relationships may delay substitution among final products) and that changes in aggregate factor endowments or in the price of energy, which alter industry employment and wages by causing factor substitution to take place, have the longest associated adjustment lags. Thus, equations (2.10) and (2.11) were estimated with lages of twenty-four months on the aggregate capital stock and labor force variables, and on the price of energy, lags of eighteen months on the aggregate price and the price of the competing import goods, and a lag of six months on real income. ${ }^{6}$ The estimates were computed using fourth degree, polynominal distributed lags (except for real income, where a thirddegree polynomial was assumed to be sufficient to capture the lag pattern).

Finally, a set of dummy variables for the months of the year was appended to

6. The short times series did not permit selection of the length of the lags on an equation-by-equation and variable-by-variable basis according to standard statistical procedures. However, selected re-estimation showed that the conclusions drawn from the a priori imposition of a particular lag structure were robust with respect to moderate changes in the lengths of the various lags. 
equations (2.1) and (2.11), to capture seasonal effects other than these associated with movements in the included exogenous variables. The estimation period was taken to be January 1969 through December 1979, comprising a total of 132 monthly observations. ${ }^{7}$

The data set was constructed as follows. First, nine industries, defined as either three or four digit S.I.C. categories, were chosen for application. These industries, all of which are generally regarded as having suffered intense competition from imports in the recent past, are as follows: hardwood veneer and plywood; leather tanning: footwear ; pottery and related ceramic products ; bolts, nuts, rivets and washers ; ball and roller bearings ; radios and televisions ; photographic equipment ; and dolls, games and toys. The industries were selected primarily on the basis of ease of construction of an import price index (see discussion below).

Some industries were eliminated because binding quantitative import restrictions were in effect during the sample period, thus violating the assumption of a perfectly elastic supply of imports. Of the industries studied, only imports of television receivers were subject to quantitative restriction, and then only for a small portion of the sample period. Furthermore, the VER on televisions, applied only to a few exporting countries (e.g. Japan, Taiwan and Korea) and other exporters (e.f. Singapore) were able to greatly expand their supplies to the U.S. market at (it seems) relatively constant cost.

Employment for each industry, measured in average man-hours per week, was taken to be the product of the number of production workers and the average number of hours worked per week. I used average hourly earnings as the measure of wages. All these series were taken from Employment and Earnings (various issues).

For the aggregate price level, I chose the wholesale price index, and aggregate industrial production was taken as a proxy for real income. These variables, as well as those for the labor force and the price of energy, were taken from the Survey of Current Business (various issues). The aggregate capital stock variable was calculated according to the formula $\mathrm{K}_{\mathrm{t}+1}=\mathrm{I}_{\mathrm{t}}+(1+\delta) \mathrm{K}_{\mathrm{t}}$, where $\mathrm{I}_{\mathrm{t}}$ is gross investment and $\delta$ is the constant rate of depreciation. For real gross investment, I used total expenditure on new plant and equipment divided by the implicit price deflator for fixed investment.

Since these data are available only on a quarterly basis, monthly values were generated by interpolation. The benchmark observation for the capital stock was taken from the Office of Business Economics (1971), and the rate of depreciation from Jorgenson and Stephenson (1967). The construction of the import price series posed the

7. In the case of one industry, namely hardwood veneers, data availability dictated an estimation period of January, 1972 through December, 1979. 
greatest problems, both conceptual and otherwise. Price indices for imports by disaggregated commodity categories are not available for the United States.

Instead, I first performed a concordance between the S.I.C. categories and the seven-digit, Schedule A import classifications. Then I calculated unit values for these finely disaggregated import groupings by dividing values by quantities. Finally, I formed fixed-weight indices of the unit values, using full-year 1974 values as weights. The tariff factors were constructed similarly, using a concordance between the S.I.C. categories and the T.S.U.S.A. classifications under which tariff rates are specified.

Specific tariffs were converted to their ad-valorem equivalents, again using values and prices for 1974. The tariff factors were adjusted in several cases to reflect temporary, escape clause protective measures, ${ }^{8}$ and all factors incorporate the ten percent import surcharge in force during the latter part of $1971 .^{9}$

The estimated, reduced-form elasticities of wage and employment levels with respect to the domentic price of the import-competing goods are reported in Table $1 .^{10}$ The figures shown represent long-run or total elasticities(i.e., the sum of the individual lag coefficients).

Almost all of the coefficient etimates are positive, as is predicted by the theory. To characterize the results, it seems that the sensitivity of employment to import prices varies significantly across industries. In the cases of leather tanning, nuts and bolts, ball bearings, photographic equipment and toys, the elasticities are quite small, so that a large change in the import price would be needed to affect a significant loss of jobs in the U.S. industries. The elasticities are moderately sized for footwear, pottery and hardwood, whereas employment in the radio and television industry is found to be very sensitive to import competition. This latter finding is consistent with the high cross-price elasticities I estimated between domestic and imported televisions in Grossman (1982b).

The estimates of wage responsiveness to import competition are more consistent across sectors. In all cases, these elasticities are small, indicating that changes in the extent of foreign competition in particular industries can effect only minor changes in

8. The various safeguard measures implemented by the United States in the last decade are listed and discussed in Gard and Riedel (1980).

9. The resulting series of tariff-adjusted import prices are presented in an appendix that is available from the author upon request.

10. The other coefficient estimates of the reduced-form equations are not of direct concern here, and are therefore relegated to an appendix that is available from the author upon request. 
the cross-sectoral structure of relative wages in the United States. This finding suggests a relatively high degree of intersectoral labor mobility.

Reduced-form parameter values of the sort presented here are useful in their own right, because they tell us, for example, the impact that proposed tariff changes would likely have on employment and wages. The conclusion in this regard is that tariffs on a number of goods could be reduced or eliminated with only minimal effect on the munber of jobs in the domestic industry or the wages paid there. At the same time, protection such as provided by escape clause measures in unlikely at any reasonable level to preserve many jobs in an industry or to halt a decline in the relative wages of a group of workers, if the relevant elasticities are small.

In order to address the question of the extent to which import competition historically has been responsible for the loss of jobs or the relative decline in wages in certain sectors, it is necessary to supplement the parameter estimates with a counterfactual path of import prices corresponding to an assumed absence of import competition. This is the task of the next section.

\section{Counterfactual Simulations}

A number of standards could conceivably be applied to measure the extent of import competition. Those that rely on the quantity of imports alone, or on the ratio of imports to domestic consumption or output, are suspect, because these variables are

\section{TABLE 1 Sensitivity of Wages and Employment to Import Prices}

\begin{tabular}{llcc}
\hline Sic Code & \multicolumn{1}{c}{ Industry Name } & Employment Elasticity $^{\mathrm{a}}$ & Wage Elasticity $^{\mathrm{a}}$ \\
\hline 2435 & Hardwood Veneer and Plywood & .734 & .007 \\
311 & Leather Tanning & $(.572)$ & $(.076)$ \\
& & .085 & .056 \\
314 & Footwear (ex.rubber) & $(.199)$ & $(.021)$ \\
& .0262 \\
326 & Pottery and related products & $(.183)$ & $(.042)$ \\
& & .608 & -.130 \\
3452 & Bolts, Nuts, Washers, Rivets & $(.191)$ & $(.082)$ \\
& & .164 & .059 \\
3562 & Ball and Roller Bearings & $(.136)$ & $(.032)$ \\
& & .068 & .061 \\
365 & Radio and Television & $(.130)$ & $(.021)$ \\
& & 3.020 & .128 \\
386 & Photographic Equipment & $(.558)$ & $(.095)$ \\
& & -.184 & .071 \\
3942, & Dolls, Games and Toys & $(.090)$ & $(.029)$ \\
3944 & & .085 & .034 \\
& & $(.260)$ & $(.024)$ \\
\hline
\end{tabular}

${ }^{a}$ Standard errors in parenthesis. 
affected not only by conditions in the foreign industries, but also by changes in tastes or production conditions at home. What is desirable, instead, is to define import competition in terms of the location and movements of the foreign import supply curve.

If foreign supply is assumed to be perfectly elastic, then import prices, rather than import quantities, should form the basis for measurement of the extent of competition. ${ }^{11}$ For the purposes of this study, a situation of neutral import competition (i.e., neither an intensification, nor an abatement) is defined as a constant relative price of the import good in terms of the domestic aggregate price level. It is a fall in the relative price of imports (not relative to the domestic price of good i, which is endogenous, but relative to domestic prices in general) which begins the process by which import competition effects a reallocation of resources. Of course, a fall in $\mathrm{p}_{i}$ relative to both $\mathrm{p}_{i}^{*}$ and $\mathrm{p}_{\mathrm{a}}$ caused by some other structural factor could begin the same reallocation process, but then it would not be appropriate to attribute responsibility for the resulting movement of resources or changes in factor prices to imports.

Equations (2.10) and (2.11), with monthly dummy variables and lag terms added, were simulated using historical data for all of the exogenous variables, except for the domestic price of imports. In place of $\mathrm{p}_{i}^{*}\left(1+\tau_{i}\right)$, I used a series generated by multiplying $\mathrm{p}_{\mathrm{a}}$ by the observation of the relative domestic price of the import in terms of the aggregate price index for January, 1967. Thus, I have generated paths for employment and wages that correspond to the counterfactual assumption of neutral import competition over the entire period, with everything else held constant. Pairs of simulations were performed for all industries, except in the two cases where the reduced-form coefficient estimates on the import price had the theoretically incorrect (i.e., negative) sign.

The hypothetical paths of employment and wages are depicted in Figures 1 through 16 , as are the historical paths of these variables. By comparing the simulated and actual values, we have an estimate of the effect of import competition in each industry. ${ }^{12}$ Some of the imformation in the figures is summarized in Table 2, where

11. If import supply has a strictly positive but finite price elasticity, then neither prices nor quantities alone can be used to measure import competition. It is then necessary to distinguish shifts in the foreign supply curve from movements along it, which can only be accomplished by estimating supply equations for each country producing competing goods.

12. Alan Deardorff has pointed out that this methodology attributes to import competition the residuals from the reduced-form estimation of the employment and wage equations. However, there residuals have an expected value of zero, so that the procedure does not introduce bias into the computation of the employment and wage effects. Furthermore, the residuals were generally quite small in absolute value, since the fits of the reducedform equations were quite good. 
TABLE 2 The Effect of Import Competition on Employment and Wages

\begin{tabular}{|c|c|c|c|c|c|c|}
\hline \multirow[t]{2}{*}{ Industry } & \multicolumn{3}{|c|}{ Employment, 1979} & \multicolumn{3}{|c|}{ Wages, 1979} \\
\hline & Actual & Simul. ${ }^{c}$ & $\%$ Diff. & Actual & Simul. ${ }^{c}$ & $\%$ Diff. \\
\hline Hardwood Veneer & $\overline{993}$ & $\overline{1111}$ & $\overline{+11.9}$ & $\overline{4.73}$ & $\overline{4.80}$ & +1.5 \\
\hline Leather Tanning & 645 & 675 & +5.0 & 5.55 & 5.57 & +0.4 \\
\hline Footwear & 4627 & 4584 & -0.9 & 4.10 & 4.20 & +2.4 \\
\hline Pottery & 1522 & 1158 & -23.9 & 5.62 & - & - \\
\hline Nuts and Bolts & 1692 & 1921 & +13.5 & 6.88 & 6.72 & -2.3 \\
\hline Ball Bearings & 1943 & 2005 & +3.2 & 7.40 & 7.95 & +7.4 \\
\hline Radio and T.V. & 3265 & 5592 & +71.3 & 5.85 & 6.16 & +5.3 \\
\hline Photographic & 2838 & - & - & 7.94 & 7.31 & -7.9 \\
\hline Dolls, Toys and & 1692 & 1682 & -0.6 & 4.48 & 4.60 & +2.7 \\
\hline
\end{tabular}

${ }^{a}$ Employment measured in thousands of manhours of production labor per week, averaged over the year.

${ }^{b}$ Wages measured as average hourly earnings.

'Simulations computed assuming :

$$
\frac{\mathrm{p}_{i}^{*}(\mathrm{t})}{\mathrm{P}_{\mathrm{a}}(\mathrm{t})}=\frac{\mathrm{P}_{i}^{*}(1967: 1)}{\mathrm{P}_{\mathrm{a}}(1967: 1)} \text { for all } \mathrm{t} \text { from } 1967: 1 \text { through } 1979: 12
$$

I present the historical and simulated average levels of employment and earnings for the year 1979 .

It is evident from Table 2 that the experience with foreign competition has not been uniform across sectors. In three industries, there would have been less average employment in 1979 than was actually observed, had import competition been neutral from 1967 to 1979 , and in two sectors wages would have been lower. In four indestries import competition has been responsible for the loss of a moderate amount of employment, ranging from 30,000 to 229,000 manhours per week. Only in the case of a single industry among the nine studied (radios and televisions) can it be said that competition from abroad has cost the United States a significant number of jobs. It is estimated that employement in the radio and television industry would have been 71 . 3 percent greater in 1979 than was observed, had import competition been neutral for the preceeding twelve years. This corresponds to a loss of approximately 60,000 jobs in this industry.

The table shows that import competition has not had a major effect on wages in most of the industries studied. In only two of the eight simulations can we attribute to imports a loss of hourly earnings in 1979 greater than ten cents per hour. Again, this evidences a fairly high degree of labor mobility out of declining sectors, at least in the long run(i.e., after eighteen months). 
Note that the methodology suggested here could be applied to a wider range of questions. For example, it would be possible to estimate the effects that the oil price increases have had on employment and wages in particular industries by replacing the historical series for $\mathrm{p}_{\mathrm{e}}$ with an assumed counterfactual. Similarly, one could simulate what the effect on the labor market would have been of various, hypothetical trade policies, such as the gradual reduction or elimination of protection. Of course, the procedure does not allow us to trace the fortunes of those who are displaced from a declining sector, as to whether, for example, they find new jobs in expanding sectors and if so, how quickly. In order to answer to these important policy questions, one would need detailed, micro-survey data.

\section{Summary and Conclusions}

In a dynamic, open economy, resource reallocations and movements in industry factor prices may have many proximate, structural causes. For example, income elasticities of demand or rates of technological progress may vary across sectors, or differences in the rates of accumulation of alternative factors of production may effect changes in relative factor prices and therefore relative costs of production. In recent years, much attention has focused on the extent to which import competition has been a major cause of labor displacements and wage movements, in comparison to these other structural determinants of the industry structure of employment and wages.

This paper has provided a new methodology for addressing this issue. First, a model is specified to determine the quantities of resources employed in a given sector, and the equilibrium factor prices there. The model assumes; (i) the existence of three factors and many goods; (ii) that two factors, labor and capital, may be imperfectly mobile between sectors, whereas the third, energy, is a traded good available in infinitely elastic supply; and (iii) that domestic output substitutes imperfectly for a competing, import good.

Due to problems of data collection the structural model was not estimated directly, but first was solved for its reduced-form. Reduced-form wage and employment equations were estimated for nine, allegedly trade-impacted manufacturing sectors in the United States. Particular emphasis was placed on the estimated elasticities of employment and wages with respect to the domestic price of imports. These coefficients indicate the sensitivity of the domestic industry labor market to import competition. It was found that, by and large, wages are not very sensitive to competition from abroad, whereas the responsiveness of employment varied widely across sectors. 
In order to attribute certain job losses or wage movements to competition from imports, it is necessary first to define a measure of the extent of import competition. Here I used the relative price of imports in terms of the domestic price aggregate as such a measure, and simulated paths for employment and wages under the counterfactual assumption that this relative price remained constant from 1967 through 1979. The difference between the paths so generated and the actual, historical paths of employment and wages is an estimate of the effect of changes in the extent of import competition. I found that employment and wages would actually have been lower in some sectors than was actually observed had import competition been neutral during the period. Even in cases where job or earnings losses could be attributed to import competition, the effect was relatively small, except in one industry(radios and televisions) where competition from abroad has had evidently a major, negative influence on both the level of employment and the wages paid to those with jobs.

\section{References}

Cable, V. (1977), "British Protectionism and LDC Imports," ODI Review, 2, pp.2948.

Frank, C.R.(1977), Foreign Trade and Domestic Aid, The Brookings Institution.

Gard, L.M. and Riedel, J. (1980), "Safeguard Protection of Industry in Developed Countries: Assessment of Implications for Developing Countries," Weltwirtschaftliches Archiv, 16, pp.471-492.

Grossman, G.M.(1982a), Comment on E.Verreydt and J.Waelbroeck, "European Community Protection against Manufactured Imports from Developing Countries : A Case Studty in the Political Economy of Protection, " in Bhagwati, J.N. (ed.), Import Competition and Response, University of Chicago Press.

Grossman, G.M. (1982b), "Import Competition from Developed and Developing Countries," The Review of Economics and Statistics, pp.271-281.

Grossman, G.M. (1983), "Partially Mobile Capital : A General Approach to TwoSector Trade Theory," Journal of International Economics, 15.

Hill, J.K. and Mendez, J.A. (1982), "Factor Mobility and the General Equilibrium Model of Production," Journal of International Ecomomics, pp.18-26.

Jorgenson, D.W. and Stephenson, J.A. (1967), "The Time Structure of Investment Behavior in the United States," The Review of Economics and Statistics, 49, pp. $16-27$.

Krueger, A.O. (1979a), "LDC Manufacturing Production and Implications for OECD Comparative Advantage," In Levenson, I. and Wheeler, J.W. (eds.), Western 
Economics in Transition: Structural Change and Adjustment Policy in Industrial Countries, Westview Press for the Hudson Institute.

Krueger, A.O. (1979b), "The Impact of Foreign Trade on Employment in U.S. Industry," in Black, J.and Hindlay, B. (eds.), Current Issues in Commercial Policy and Diplomacy, Macmillan Press.

Krueger, A.O.(1980a), "Protectionist Pressures, Imports and Employment in the United States," Scandinavian Journal of Economics, 82, pp.133-146.

Krueger, A.O. (1980b), "Restructuring for Import Competition from Developing Countries, I: Labor Displacements and Economic Redeployment in the United States," Journal of Policy Modeling, 2, pp.165-184.

Martin, J.P. and Evans, J.(1981), "Notes on Measuring the Employment Displacement Effects of Trade by the Accounting Procedure," Oxford Economic Papers, 33, pp.154-164.

Mussa, M. (1982), "Imperfect Factor Mobility and the Distribution of Income," Journal of International Economics, 12, pp.125-142.

Office of Business Exonomics(1971), Fixed Residential Business Capital in the United States, 1925-1970, U.S. Government Printing Office. 
Figure 1.

ACTUAL AND SIMULATED PATHS OF EMPLOYMENT HARDWOOD VENEER AND PLYWOOD (SIC 2435)

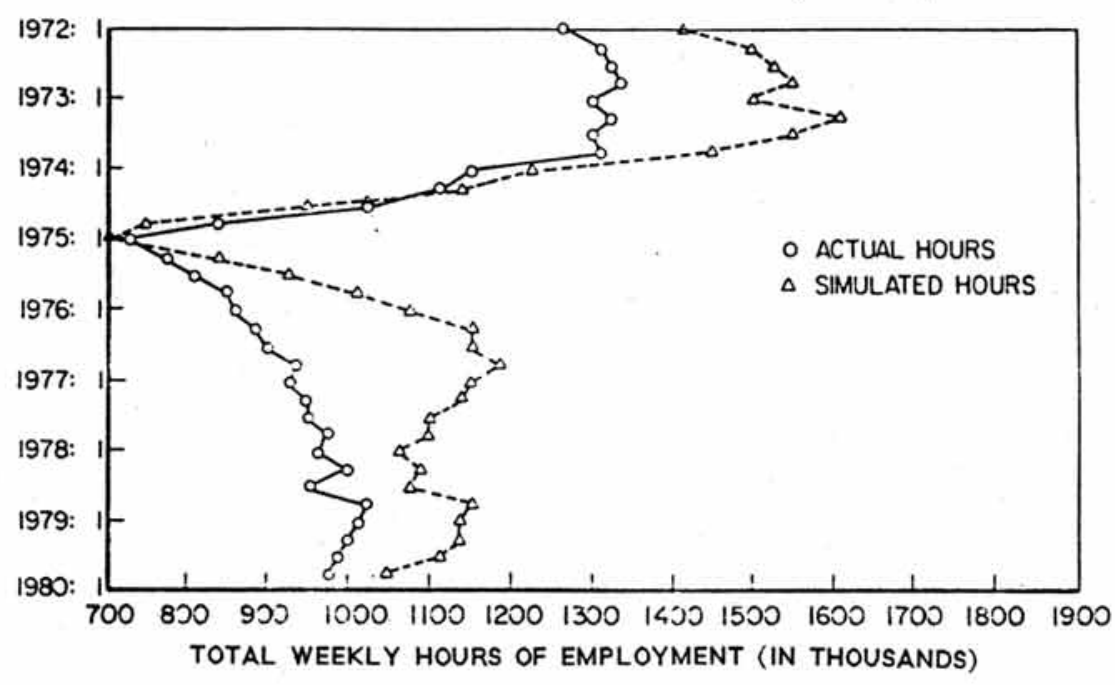

Figure 2. HARDWOOD VENEER AND PLYWOOD (SIC 2435)

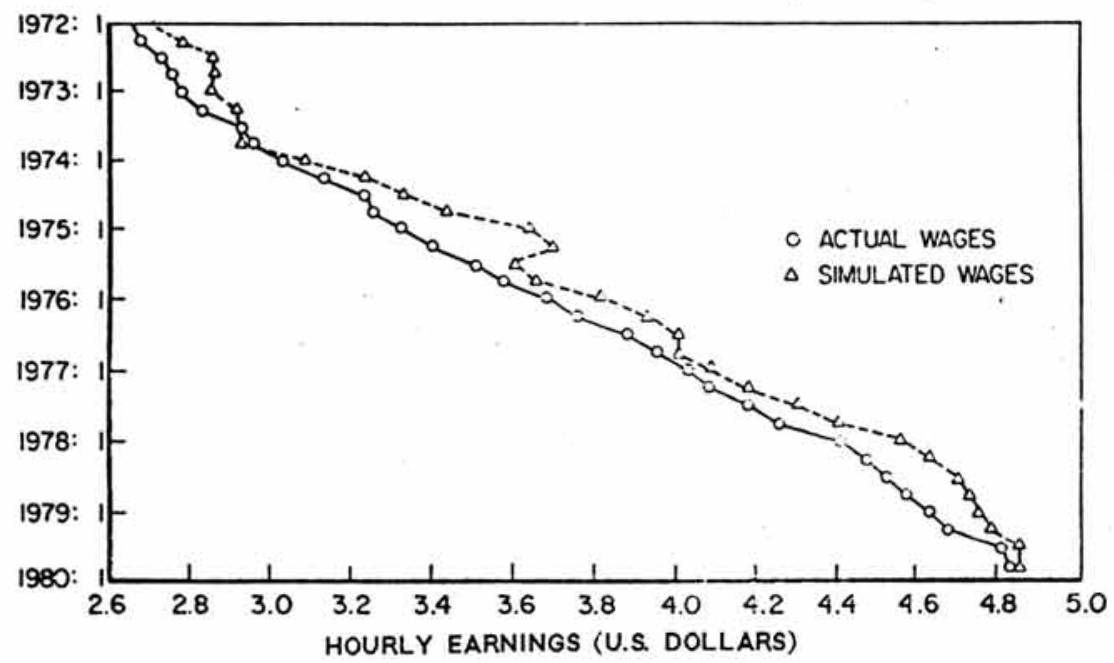


Figure 3.

ACTUAL AND SIMULATED PATHS OF EMPLOYMENT LEATHER TANNING (SIC 311)

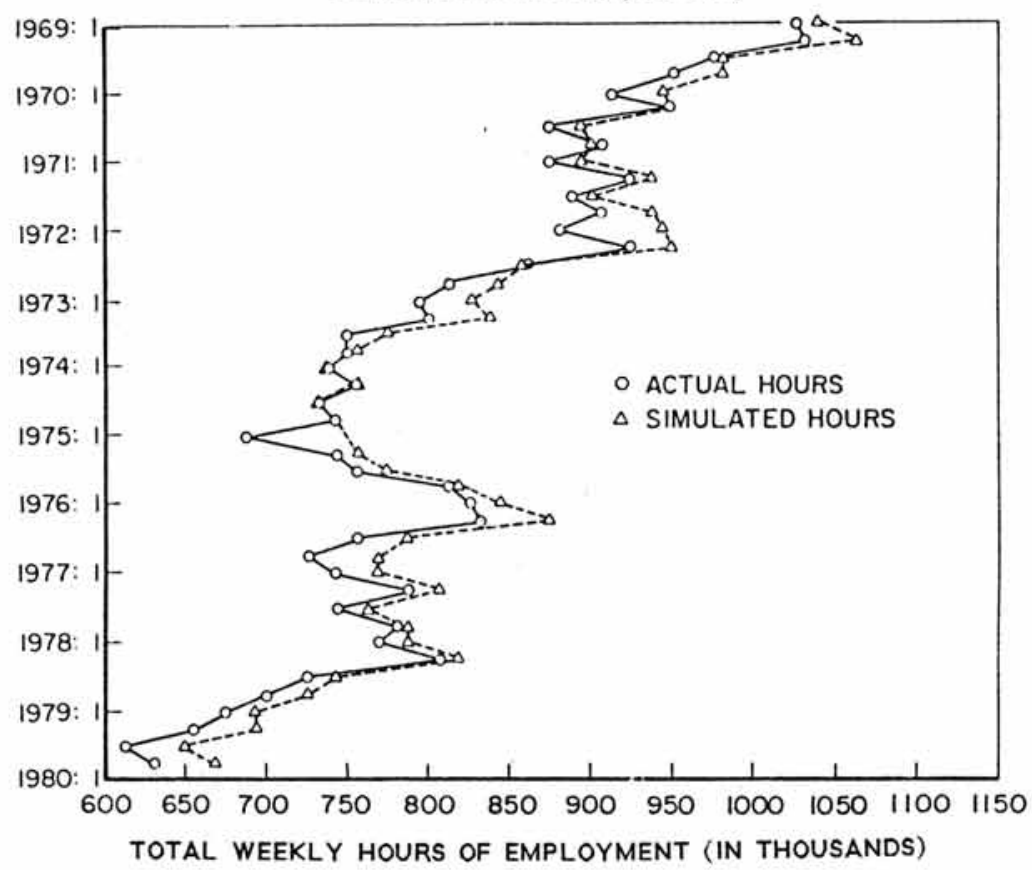

Figure 4 .

ACTUAL AND SIMULATED PATHS OF WAGES LEATHER TANNING (SIC 311)

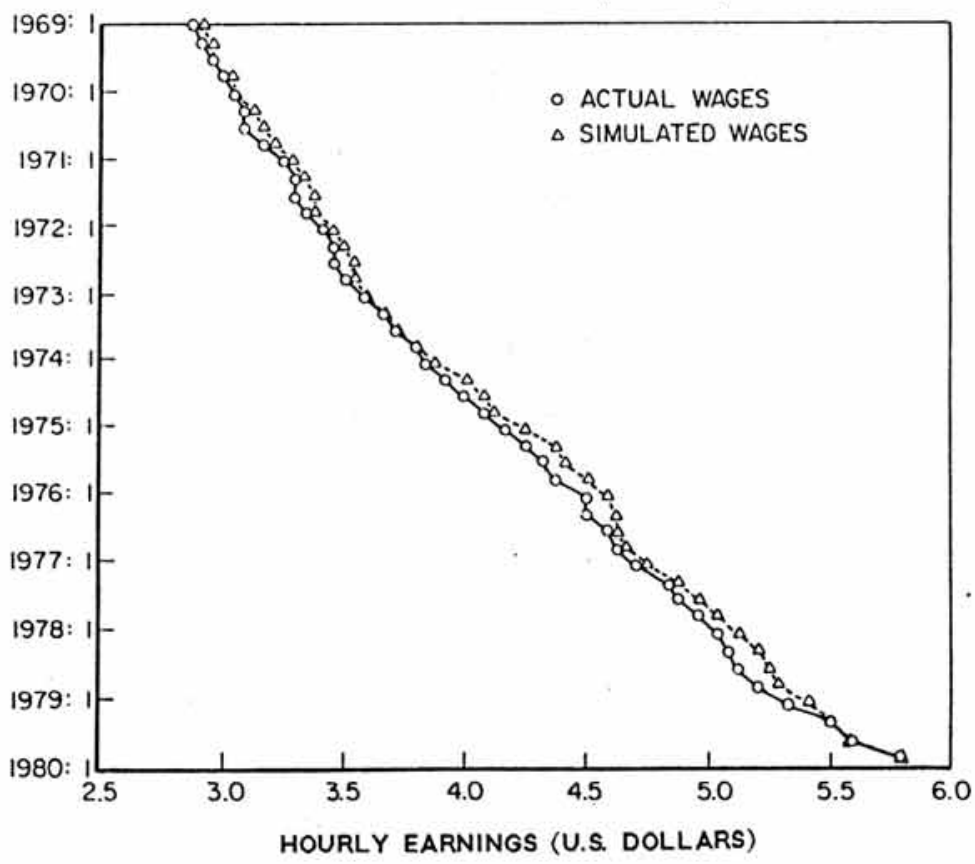


Figure 5.

Figure 6 .
ACTUAL AND SIMULATED PATHS OF EMPLOYMENT FOOTWEAR, EXC. RUBBER (SIC 314)

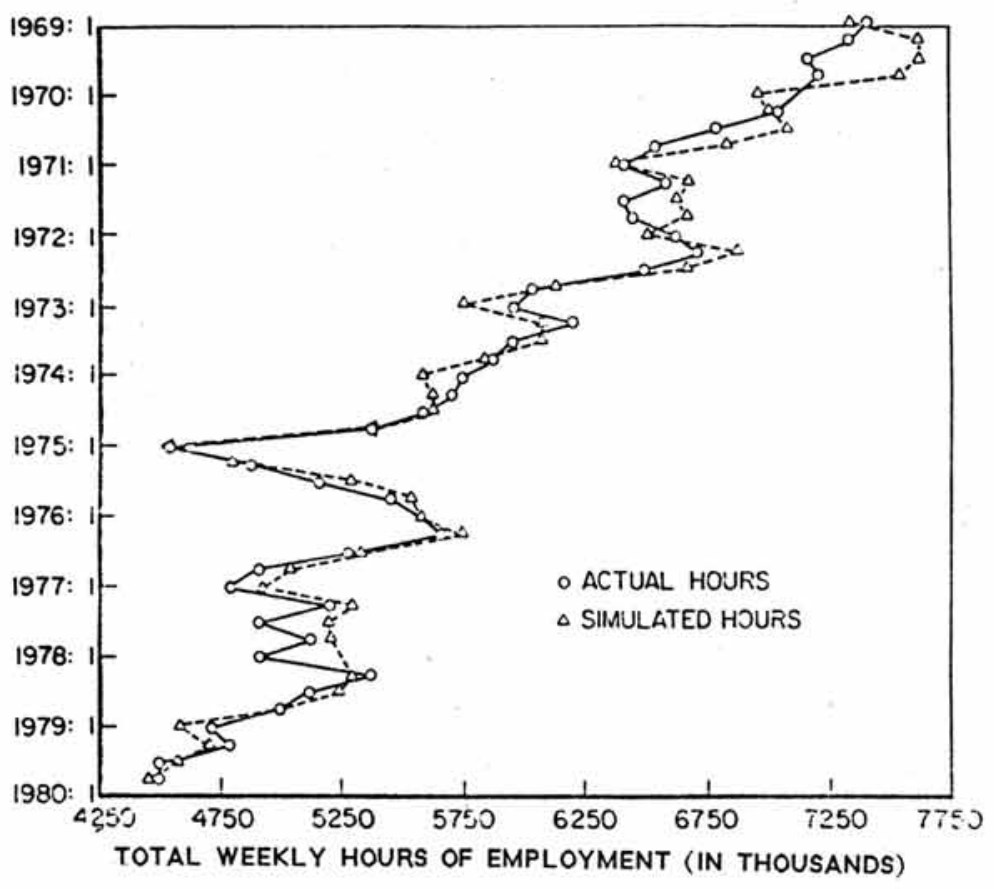

ACTUAL AND SIMULATED PATHS OF WAGES FOOTWEAR, EXC. RUBBER (SIC 314)

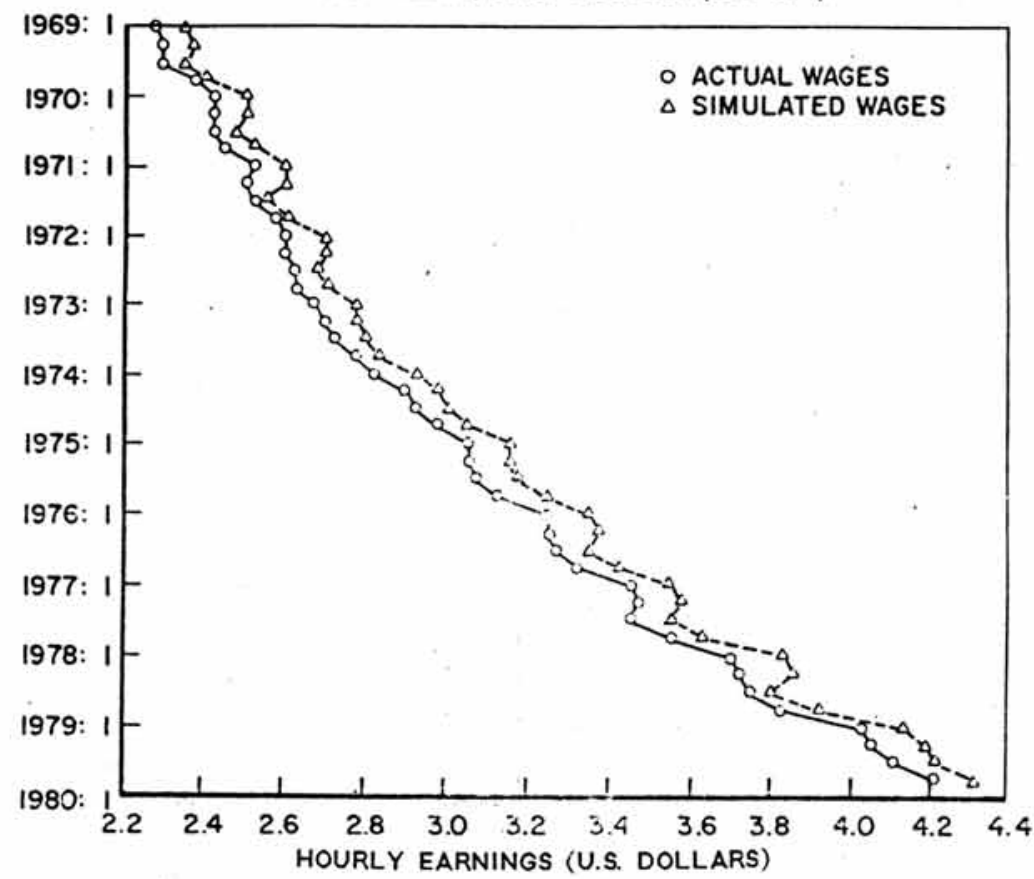


Figure 7 .

Figure 8 . 


\section{Figure 9 .}

ACTUAL AND SIMULATED PATHS OF WAGES

NUTS, BOLTS, RIVETS \& WASHERS (SIC 3452)

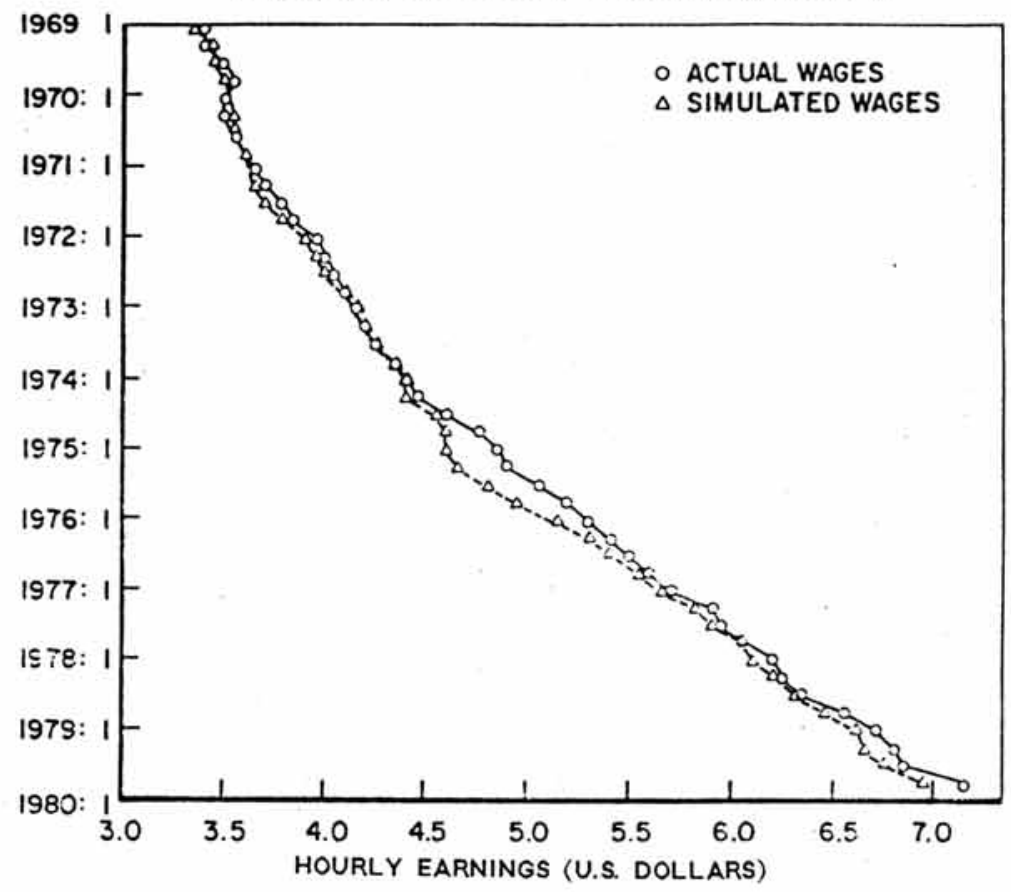

Figure 10.

ACTUAL AND SIMULATED PATHS OF EMPLOYMENT

BALL AND ROLLER BEARINGS (SIC 3562)

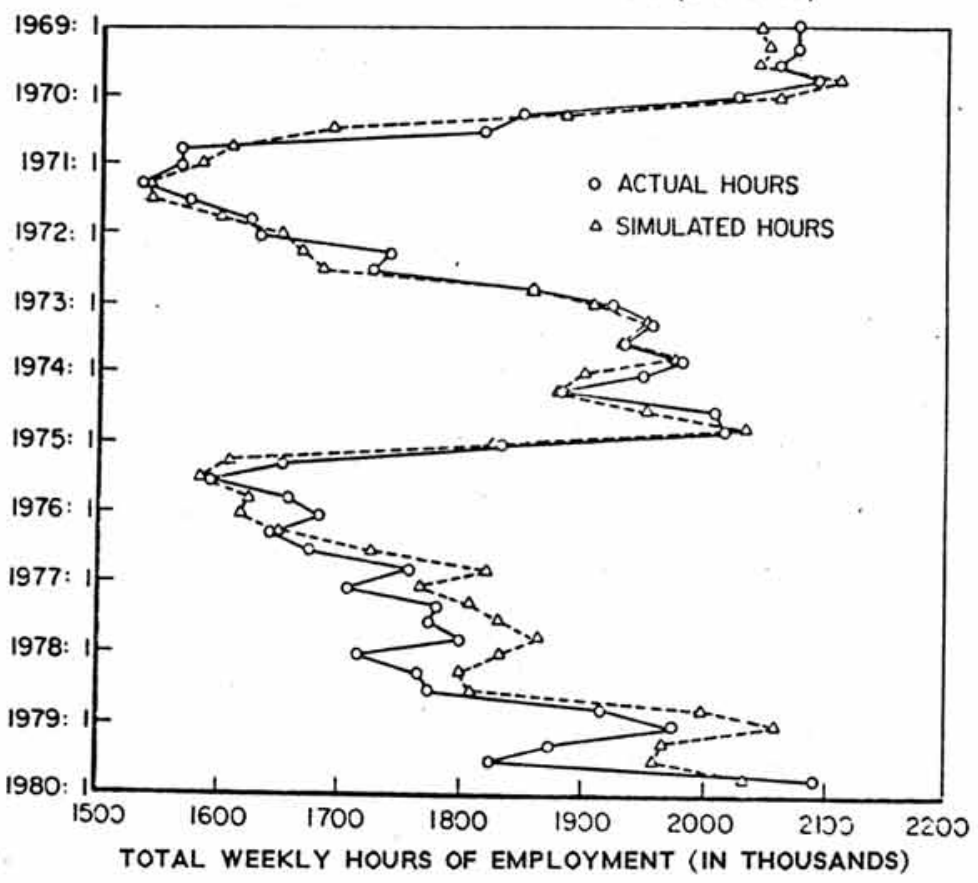


Figure 11.

ACTUAL AND SIMULATED PATHS OF WAGES

BALL AND ROLLER BEARINGS (SIC 3562)

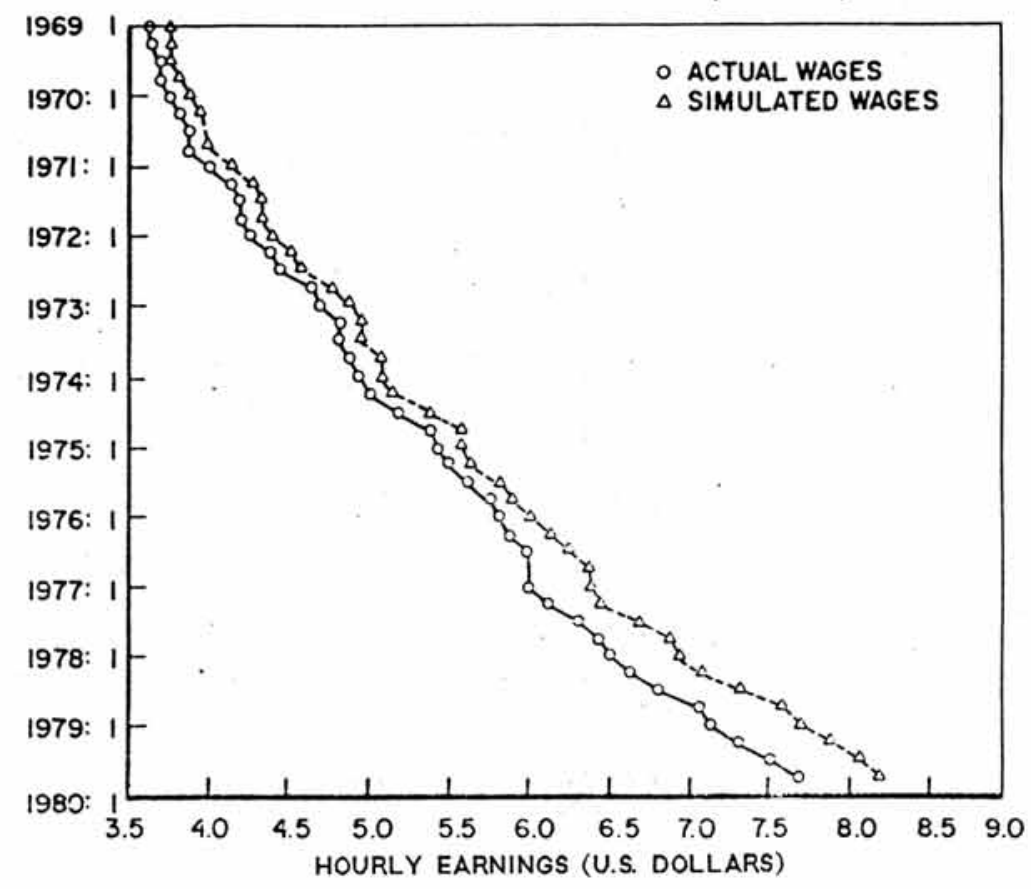

Figure 12 .

ACTUAL AND SIMULATED PATHS OF EMPLOYMENT RADIO AND TELEVISION (SIC 365)

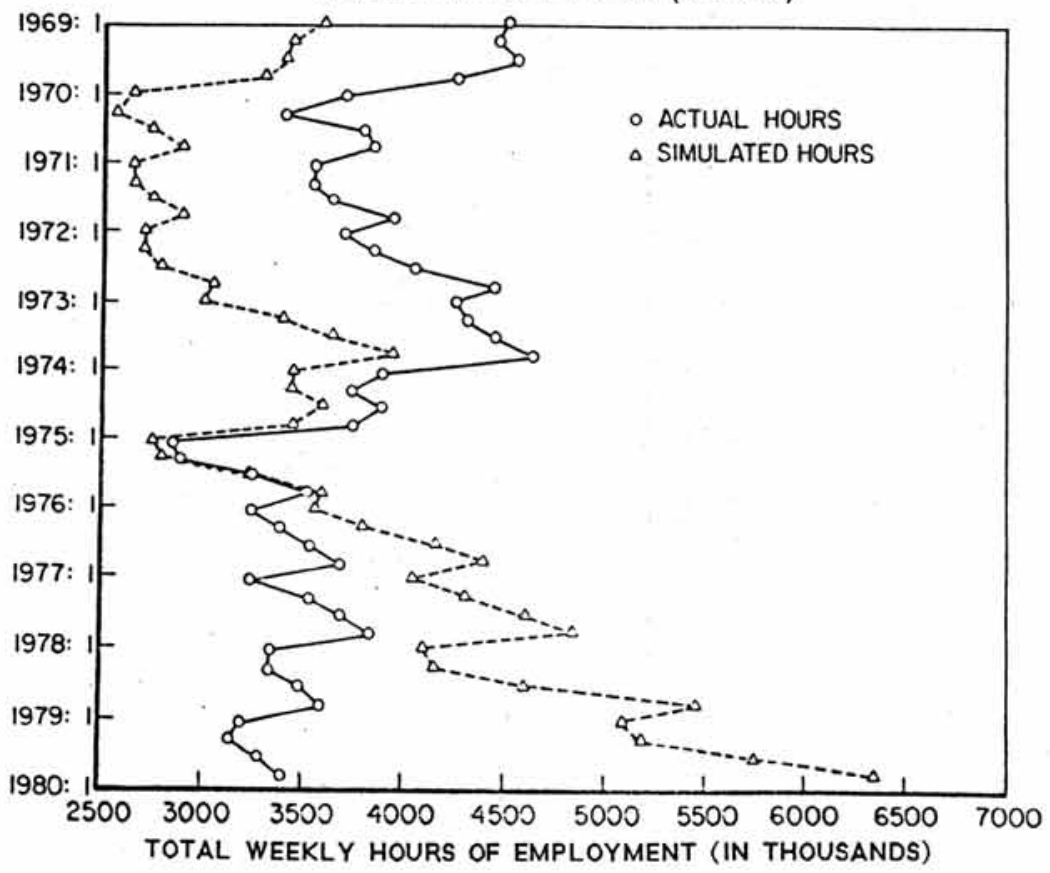


Figure 13.

ACTUAL AND SIMULATED PATHS OF WAGES

RADIO AND TELEVISICN (SIC 365)

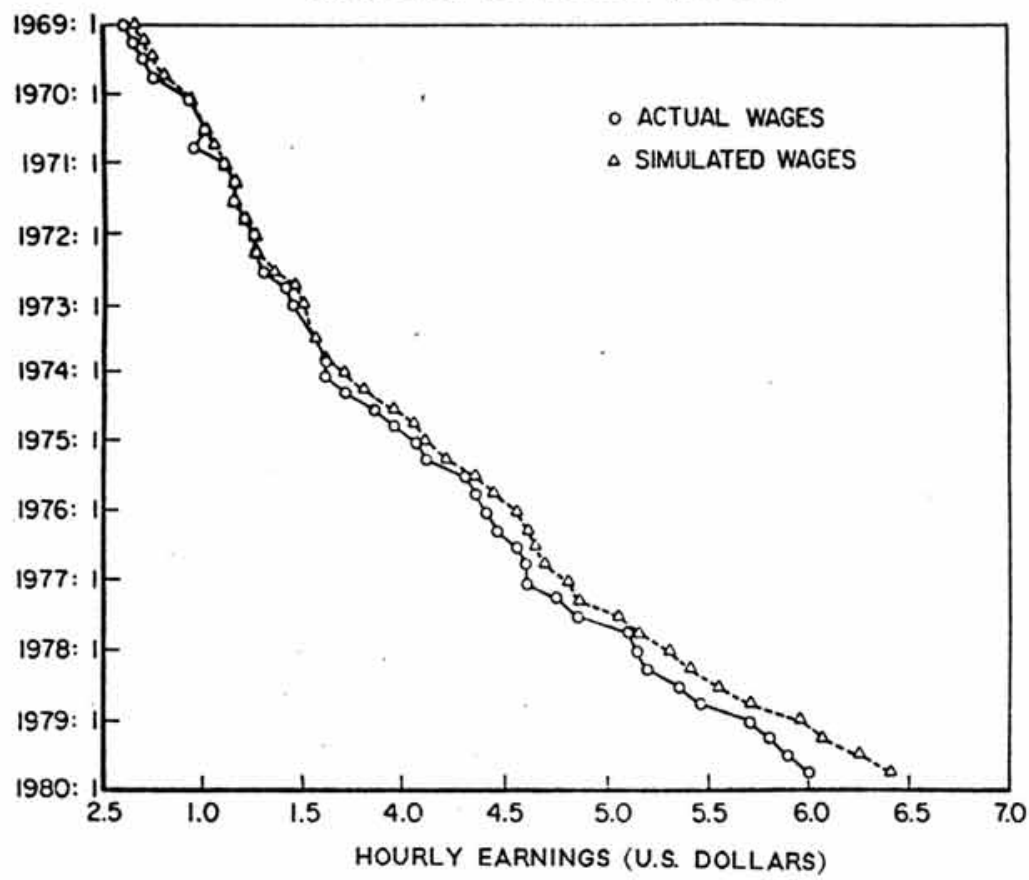

Figure 14 .

ACTUAL AND SIMULATED PATHS OF WAGES

PHOTOGRAPHIC EQPT. (SIC 386)

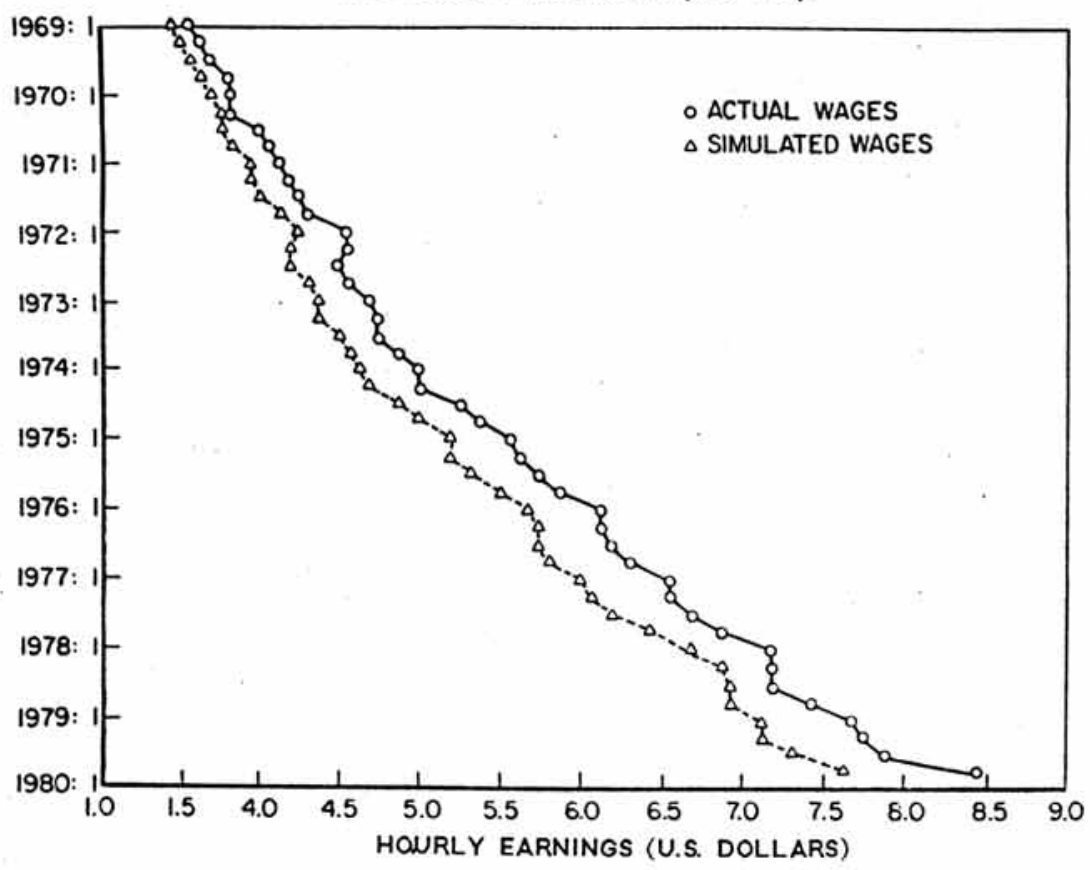


Figure 15 .

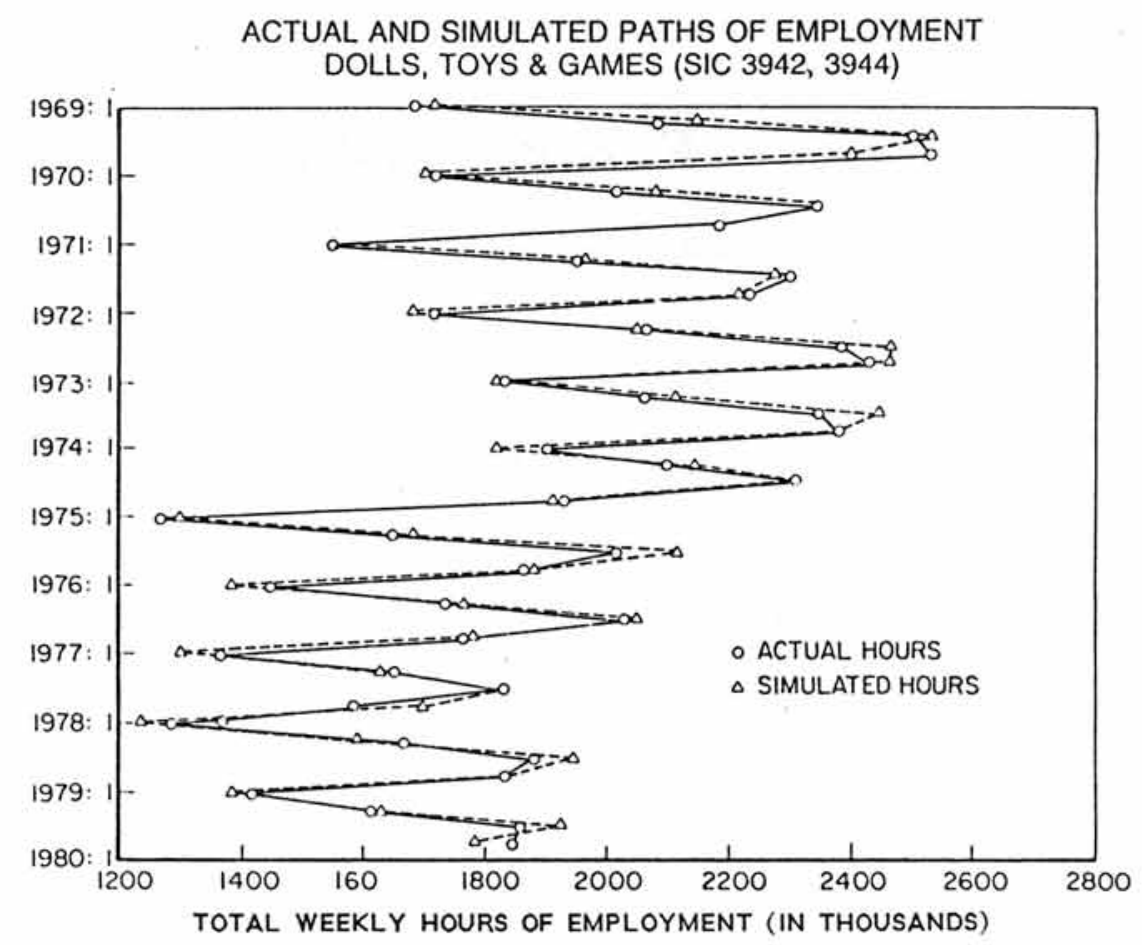

Figure 16 .

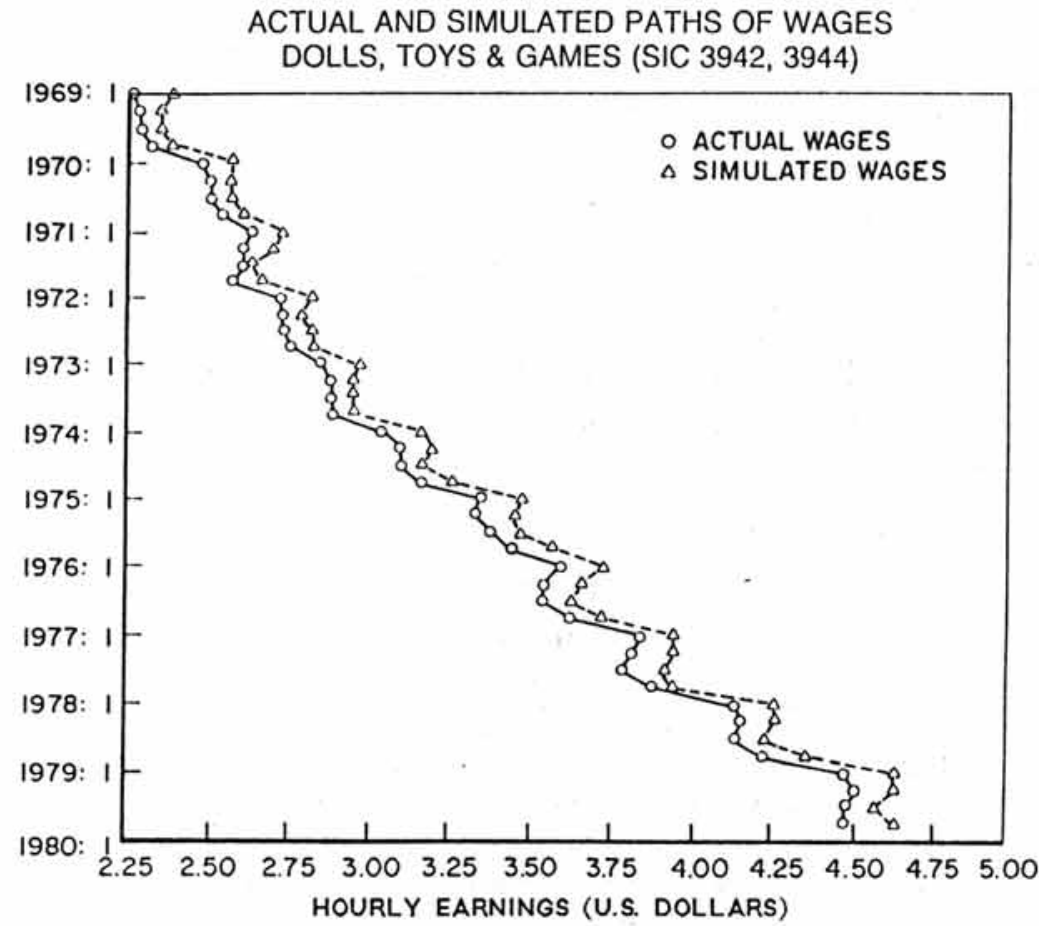

